\title{
Studies on lipase-catalyzed asymmetric synthesis of (S)-(hydroxymethyl)glutamic acid (HMG)
}

\author{
Hiromasa Yoshioka and Masato Oikawa*
}

\begin{abstract}
(S)-(Hydroxymethyl)glutamic acid was successfully synthesized in total $12 \%$ yield over eight steps from tris(hydroxymethyl)aminomethane hydrochloride (Tris. $\mathrm{HCl}$ ), employing lipase TL-induced enantioselective acetylation of a prochiral 1,3-diol as the key step.
\end{abstract}

Keywords: Glutamate analogs, Lipase-catalyzed acetylation, (Hydroxymethyl)glutamic acid, Asymmetric synthesis

\section{Background}

The metabotropic glutamate receptors (mGluRs) play an important role in the modulation of synaptic transmission and neuronal excitability by glutamate, the main excitatory neurotransmitter, in the central nervous system (CNS) (Niswender and Conn 2010; Rondard and Pin 2015). mGluRs are members of the G-protein-coupled receptor (GPCR) superfamily, and belong to family $C$ receptors that typically contain the endogenous ligandbinding site at a large extracellular $\mathrm{N}$-terminal domain. mGluRs are subdivided into three groups, group I (mGluRs 1 and 5), group II (mGluRs 2 and 3), and Group III (mGluRs 4, 6, 7, and 8). Group II mGluRs reduce cAMP accumulation resulting in neuroprotecting effect and are closely linked to construction of memory and learning (Kawasaki et al. 2003). (Hydroxymethyl)glutamic acid (HMG) is one of the selective ligands for group II mGluRs. (R)-HMG is a selective agonist for mGluR3 (Miyaoka et al. 2006), and the (S)-counterpart [(S)-HMG, Fig. 1] has been shown to act as a more potent agonist for mGluR3 and a weak antagonist for mGluR2, both belong to group II (Choudhury et al. 2002).

Several practical synthetic studies of HMG have been so far reported. In 2001, the first synthesis of HMG has been reported by Kozikowski group (Zhang et al. 2001)

*Correspondence: moikawa@yokohama-cu.ac.jp

Yokohama City University, Seto 22-2, Kanazawa-ku, Yokohama 236-0027, Japan

\section{Springer}

(c) 2015 Yoshioka and Oikawa. This article is distributed under the terms of the Creative Commons Attribution 4.0 International License (http://creativecommons.org/licenses/by/4.0/), which permits unrestricted use, distribution, and reproduction in any medium, provided you give appropriate credit to the original author(s) and the source, provide a link to the Creative Commons license, and indicate if changes were made. employing Michael addition followed by ring closure. The same strategy has been employed in the synthesis reported by the group led by Jimenez-Oses and Avenoza (Aydillo et al. 2011). Synthesis by Strecker reaction (Choudhury et al. 2002; Kawasaki et al. 2003; Tang et al. 2004) has been proven to be also powerful. A number of other synthetic studies includes aldol reaction (Battistini et al. 2004), C-H insertion (Hayes et al. 2006), lipasemediated acetylation of cyclic substrate (Miyaoka et al. 2006), chiral auxiliary-assisted diastereoselective alkylation (Yiotakis et al. 2007), and selective transformation of xylofuranose used as a chiral pool (Martinkova et al. 2008), as the key steps.

We have been also interested in the synthesis of the neuronally active compounds, by the divergent route amenable to the structural analogs to discover novel compounds (Chiba et al. 2015; Juknaitè et al. 2013; Oikawa et al. 2013; Sakai et al. 2014; Sugeno et al. 2014; Tanaka et al. 2015). Here, we report our synthetic study using lipase-mediated esterification of prochiral acyclic 1,3-diol as the key step. Although such enzymatic strategy has been previously reported as noted above (Miyaoka et al. 2006), in this study, we intended development of our own route not only to HMG but also to the analogs. Furthermore, enzymatic approach was expected to be applicable to the other biologically interesting natural products such as dysibetaine (Sakai et al. 1999) and sphingofungin E (Horn et al. 1992), by virtue of (1) the 


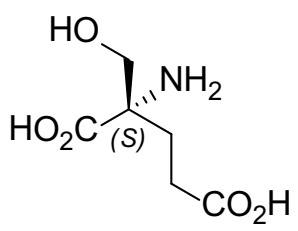

(S)-HMG

Fig. 1 (S)-(Hydroxymethyl)glutamic acid ((S)-HMG), the group II mGluR ligand

high catalytic activity and the enantioselectivity for a variety of substrates, and (2) the easy handling even in a large-scale synthesis.

\section{Methods}

All reactions susceptible to moisture and air were carried out in an atmosphere of argon gas, using the glassware oven-dried over $3 \mathrm{~h}$, and in the solvents freshly distilled from sodium and benzophenone. All other chemicals were purchased at the highest commercial grade and used directly. Lipase TL was kindly provided by Meito Sangyo Co., Ltd., Japan. Analytical thin-layer chromatography (TLC) was performed using Merck silica gel 60 F254 plate (0.25-mm thickness). Flash column chromatography was carried out using Merck silica gel 60 (230-400 mesh) or Fuji Silysia silica gel BW-300 (200-400 mesh). Reversedphase silica gel column chromatography was carried out using Fuji Silysia Chromatorex DM1020T (0.10-mm thickness). For high-performance liquid chromatography (HPLC), recycling preparative system LC-918 (Japan Analytical Industries) was used. The analytical and preparative chiral HPLC experiments were performed on a JASCO PU-2080 system equipped with ELS-2041, using CHIRALPAK IC column $(0.46 \times 25 \mathrm{~mm})$. IR spectra were recorded on a PerkinElmer Spectrum One FT-IR spectrometer. ${ }^{1} \mathrm{H}$ and ${ }^{13} \mathrm{C}$ NMR spectra were recorded on a BRUKER AVANCE 400 spectrometer. Chemical shift values are reported in $\delta(\mathrm{ppm})$ with reference to internal residual solvent $\left[{ }^{1} \mathrm{H} \mathrm{NMR}, \mathrm{CDCl}_{3}(7.24), \mathrm{D}_{2} \mathrm{O}(4.70) ;{ }^{13} \mathrm{C}\right.$ $\mathrm{NMR}, \mathrm{CDCl}_{3}$ (77.0)]. Coupling constants $(J)$ are reported in Hertz $(\mathrm{Hz})$. The following abbreviations were used to designate the multiplicities; $\mathrm{s}=$ singlet, $\mathrm{d}=$ doublet, $\mathrm{t}=$ triplet, $\mathrm{q}=$ quartet, $\mathrm{m}=$ multiplet, $\mathrm{br}=$ broad.

\section{tert-Butyl (5-(hydroxymethyl)-2-phenyl-1,3-dioxan-5-yl) carbamate (2a)}

To a stirred suspension of tris(hydroxymethyl)aminomethane hydrochloride (Tris. $\mathrm{HCl}, \mathbf{1}, 30.1 \mathrm{~g}, 191 \mathrm{mmol}$ ) in DMF $(200 \mathrm{~mL})$ at $\mathrm{rt}$ were added $\mathrm{TsOH} \cdot \mathrm{H}_{2} \mathrm{O}(1.82 \mathrm{~g}$, $9.54 \mathrm{mmol})$ and benzaldehyde dimethyl acetal $(29.1 \mathrm{~mL}$, $0.210 \mathrm{mmol}$ ). After being stirred for $24 \mathrm{~h}$, to the resulting clear and colorless solution was added $\mathrm{Et}_{3} \mathrm{~N}(1.6 \mathrm{~mL}$,
$11 \mathrm{mmol}$ ) and stirring was continued for additional $10 \mathrm{~min}$. The mixture was then concentrated in vacuo, and $\mathrm{Et}_{3} \mathrm{~N}(21.0 \mathrm{~mL}, 149 \mathrm{mmol})$ and EtOAc $(750 \mathrm{~mL})$ were added. White precipitate was removed by filtration, and the filtrate was concentrated in vacuo to afford crude benzylidene acetal $(36.6 \mathrm{~g})$ as a yellow oil.

To a stirred solution of the crude amine thus obtained above in water $(87 \mathrm{~mL})$ and 1,4-dioxane $(87 \mathrm{~mL})$ at rt was added $\mathrm{K}_{2} \mathrm{CO}_{3}(72.5 \mathrm{~g}, 525 \mathrm{mmol})$. After being stirred for $30 \mathrm{~min}, \mathrm{Boc}_{2} \mathrm{O}$ (42.0 g, $192 \mathrm{mmol}$ ) was added. After $2 \mathrm{~h}$, the mixture was poured into saturated aqueous $\mathrm{NH}_{4} \mathrm{Cl}$ $(30 \mathrm{~mL})$. The aqueous layer was separated and extracted with EtOAc $(3 \times 300 \mathrm{~mL})$. The combined extracts were washed with brine $(50 \mathrm{~mL})$, dried over $\mathrm{Na}_{2} \mathrm{SO}_{4}$, and concentrated in vacuo. The residue was purified by precipitation from EtOAc $(50 \mathrm{~mL})$ to give diastereomerically pure $N$-Boc-protected benzylidene acetal 2a (30.7 g, $52 \%$ for two steps) as a white solid: IR (KBr) 3445, 3259, 2979, $1682 \mathrm{~cm}^{-1}$; ${ }^{1} \mathrm{H}$ NMR (400 $\left.\mathrm{MHz}, \mathrm{CDCl}_{3}\right) \delta 7.51-7.33$ $(\mathrm{m}, 5 \mathrm{H}), 5.45(\mathrm{~s}, 1 \mathrm{H}), 4.19(\mathrm{~d}, J=11.6 \mathrm{~Hz}, 2 \mathrm{H}), 3.82(\mathrm{~d}$, $J=11.7 \mathrm{~Hz}, 2 \mathrm{H}), 3.69$ (s, 2H), 1.45 (s, 9H); ${ }^{13} \mathrm{C}$ NMR $\left(100 \mathrm{MHz}, \mathrm{CDCl}_{3}\right) \delta 156.8,137.5,129.3(\times 2), 128.4$, 126.0 (×2), 102.0, 80.7, 71.8, 64.8, $53.6(\times 2), 28.4(\times 3)$. The spectroscopic data were identical to those reported (Ko et al. 2011; Schmidt and Riedl 1993).

\section{tert-Butyl (5-formyl-2-phenyl-1,3-dioxan-5-yl)carbamate (3)}

To a stirred solution of alcohol $2 \mathbf{a}(587 \mathrm{mg}, 1.90 \mathrm{mmol})$ in $\mathrm{CH}_{2} \mathrm{Cl}_{2}(20 \mathrm{~mL})$ at $\mathrm{rt}$ were added powdered MS4A (activated, $1.0 \mathrm{~g}$ ), NMO (445 $\mathrm{mg}, 3.80 \mathrm{mmol}$ ), and TPAP (34.0 mg, $0.0954 \mathrm{mmol}$ ). After $6 \mathrm{~h}$, insoluble materials were removed by filtration through a pad of Celite, and the filtrate was concentrated in vacuo. The residue was purified by silica gel column chromatography (300 g, EtOAc/hexane $=2: 8$ ) to give diastereomerically pure aldehyde 3 (350 mg, $60 \%$ ) as a white solid: IR (KBr) 3440, 3414, 2977, 1726, $1692 \mathrm{~cm}^{-1}$; ${ }^{1} \mathrm{H}$ NMR (400 MHz, $\left.\mathrm{CDCl}_{3}\right) \delta 9.51(\mathrm{~s}, 1 \mathrm{H}), 7.49-7.36(\mathrm{~m}, 5 \mathrm{H}), 5.44(\mathrm{~s}, 1 \mathrm{H})$, $4.23(\mathrm{~d}, J=11.4 \mathrm{~Hz}, 2 \mathrm{H}), 4.07$ (d, $J=11.2 \mathrm{~Hz}, 2 \mathrm{H}), 1.46$ (s, 9H); $\left.{ }^{13} \mathrm{C} \mathrm{NMR} \mathrm{(100} \mathrm{MHz,} \mathrm{CDCl}_{3}\right) \delta 198.7,155.8$, $137.2,129.4(\times 2), 128.4(\times 2), 126.0,101.5,80.9,69.4,60.4$ $(\times 2), 28.3(\times 3)$. The spectroscopic data were identical to those reported (Ko et al. 2011; Schmidt and Riedl 1993).

\section{(E)-tert-Butyl 3-(5-((tert-butoxycarbonyl)} amino)-2-phenyl-1,3-dioxan-5-yl)acrylate (4)

To a stirred solution of aldehyde 3 (350 mg, $1.14 \mathrm{mmol}$ ) in $\mathrm{CH}_{2} \mathrm{Cl}_{2}(10 \mathrm{~mL})$ at $35{ }^{\circ} \mathrm{C}$ were added tert-butyl (triphenylphosphoranylidene)acetate (643 mg, $1.71 \mathrm{mmol})$. After $2 \mathrm{~h}$, the mixture was concentrated in vacuo. The residue was purified by silica gel column chromatography $(10 \mathrm{~g}$, EtOAc/hexane $=2: 8)$ to give diastereomerically pure $\alpha, \beta$-unsaturated ester 4 (422 $\mathrm{mg}, 92 \%$ ) as a 
white solid: IR (KBr) 3385, 2979, 2932, 2870, $1706 \mathrm{~cm}^{-1}$; ${ }^{1} \mathrm{H}$ NMR $\left(400 \mathrm{MHz}, \mathrm{CDCl}_{3}\right) \delta 7.54-7.40(\mathrm{~m}, 5 \mathrm{H}), 6.80(\mathrm{~d}$, $J=16.2 \mathrm{~Hz}, 1 \mathrm{H}), 5.94(\mathrm{~d}, J=16.2 \mathrm{~Hz}, 1 \mathrm{H}), 5.52(\mathrm{~s}, 1 \mathrm{H})$, $4.33(\mathrm{~d}, J=10.6 \mathrm{~Hz}, 2 \mathrm{H}), 3.89(\mathrm{~d}, J=11.5 \mathrm{~Hz}, 2 \mathrm{H}), 1.51$ (s, 9H), 1.48 (s, 9H); ${ }^{13} \mathrm{C}$ NMR (100 MHz, $\left.\mathrm{CDCl}_{3}\right) \delta 165.1$, 154.7, 143.6, 137.3, 129.4, 128.4 (×2), $126.0(\times 2), 124.2$, $101.8,80.9,80.1,72.1,53.2(\times 2), 28.4(\times 3), 28.1(\times 3)$.

\section{tert-Butyl 4-((tert-butoxycarbonyl)} amino)-5-hydroxy-4-(hydroxymethyl)pentanoate (5)

To a solution of alkenyl acetal 4 (422 $\mathrm{mg}, 1.04 \mathrm{mmol})$ in $\mathrm{MeOH}(10 \mathrm{~mL})$ at $\mathrm{rt}$ was added $\mathrm{Pd} / \mathrm{C}(10 \% \mathrm{w} / \mathrm{w}, 40 \mathrm{mg})$, and the flask was purged with $\mathrm{H}_{2}$. After stirring for $3 \mathrm{~h}$, the mixture was filtered through a pad of Celite using $\mathrm{MeOH}(10 \mathrm{~mL})$. The solvent was removed under reduced pressure, and the residue was purified by silica gel column chromatography ( $3 \mathrm{~g}$, EtOAc/hexane $=1: 1)$ to give diol 5 (194 mg, $58 \%$ ) as a white solid: IR (film) 3358, 2978, 2363, $1714 \mathrm{~cm}^{-1} ;{ }^{1} \mathrm{H}$ NMR $\left(400 \mathrm{MHz}, \mathrm{CDCl}_{3}\right) \delta$ $3.61(\mathrm{~d}, J=11.9 \mathrm{~Hz}, 2 \mathrm{H}), 3.47(\mathrm{~d}, J=11.9 \mathrm{~Hz}, 2 \mathrm{H}), 2.30(\mathrm{t}$, $J=6.8 \mathrm{~Hz}, 2 \mathrm{H}), 1.93(\mathrm{t}, J=6.8 \mathrm{~Hz}, 2 \mathrm{H}), 1.42(\mathrm{~s}, 9 \mathrm{H}), 1.40$ (s, 9H); ${ }^{13} \mathrm{C}$ NMR $\left(100 \mathrm{MHz}, \mathrm{CDCl}_{3}\right) \delta 174.4,156.4,81.4$, 80.3, $65.3(\times 2), 29.5,28.3(\times 3), 28.3(\times 3), 28.0,26.3$.

\section{tert-Butyl (R)-5-acetoxy-4-((tert-butoxycarbonyl)} amino)-4-(hydroxymethyl)pentanoate (6) (lipase TL-catalyzed enzymatic reaction, entry 8 in Table 1)

To a stirred solution of diol 5 (4.59 $\mathrm{mg}, 0.0144 \mathrm{mmol})$ in $\mathrm{CH}_{2} \mathrm{Cl}_{2}(0.600 \mathrm{~mL})$ at $\mathrm{rt}$ were added lipase TL $(5.03 \mathrm{mg})$ and vinyl acetate $(0.00265 \mathrm{~mL}, 0.0287 \mathrm{mmol})$. After 3 days, insoluble materials were removed by filtration through a pad of Celite, and the filtrate was concentrated in vacuo. Chiral HPLC analysis [Chiralcel IC column, $20 \%$ ethanol in hexane, $1.0 \mathrm{~mL} / \mathrm{min}, \lambda=210 \mathrm{~nm}$, $\mathrm{tR}=7.0,7.5$ (major)] of the residue showed that the reaction proceeded in $33 \%$ yield with 88:12 enantioselectivity. The crude material was purified by silica gel column chromatography $(500 \mathrm{mg}$, EtOAc/hexane $=4: 6)$ to give monoacetate $6(1.60 \mathrm{mg}, 0.00443 \mathrm{mmol}, 30 \%)$ as a colorless oil, which was further purified to be $100 \%$ ee by preparative chiral HPLC.

Data for monoacetate $6(100 \% \mathrm{ee}):[\alpha]_{\mathrm{D}}^{25}-18.1(c 0.064$, $\mathrm{CHCl}_{3}$ ); IR (film) 3361, 2978, 2931, 2360, $1722 \mathrm{~cm}^{-1} ;{ }^{1} \mathrm{H}$ $\operatorname{NMR}\left(400 \mathrm{MHz}, \mathrm{CDCl}_{3}\right) \delta 4.28(\mathrm{~d}, J=11.3 \mathrm{~Hz}, 1 \mathrm{H}), 4.14$ $(\mathrm{d}, J=11.3 \mathrm{~Hz}, 1 \mathrm{H}), 3.63(\mathrm{~d}, J=11.8 \mathrm{~Hz}, 1 \mathrm{H}), 3.55(\mathrm{~d}$, $J=11.8 \mathrm{~Hz}, 1 \mathrm{H}), 2.36-2.22(\mathrm{~m}, 2 \mathrm{H}), 2.08(\mathrm{~s}, 3 \mathrm{H}), 2.05$ $(\mathrm{m}, 1 \mathrm{H}), 1.85(\mathrm{~m}, 1 \mathrm{H}), 1.43(\mathrm{~s}, 9 \mathrm{H}), 1.41(\mathrm{~s}, 9 \mathrm{H}) ;{ }^{13} \mathrm{C}$ NMR $\left(100 \mathrm{MHz}, \mathrm{CDCl}_{3}\right) \delta 173.1,171.1,155.7,81.0,80.3,77.3$, 65.0, 58.1, 29.3, $28.3(\times 3), 28.1(\times 3), 27.6,20.9$.
Table 1 Screening of lipases for enantioselective acetylation of diol $5^{a}$
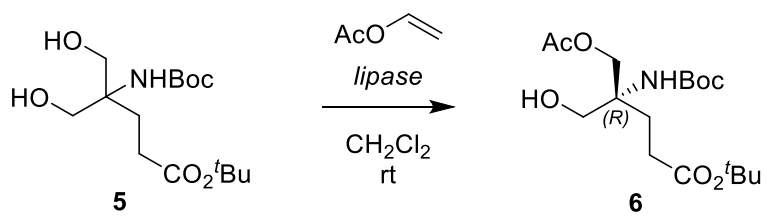

\begin{tabular}{lllll}
\hline Entry & Lipase & Time (h) & Conversion (\%) $^{\mathbf{b}}$ & Ee of $\mathbf{6}(\%)^{\mathbf{c}}$ \\
\hline 1 & AK & 21 & N.R. & - \\
2 & PS-IM & 48 & N.R. & - \\
3 & XP-488 & 72 & N.R. & - \\
4 & OF & 24 & N.R. & - \\
5 & QLM & 72 & 59 & 47 \\
6 & PL & 24 & 29 & 41 \\
7 & Novozyme 435 & 24 & 42 & 9.5 \\
8 & TL & 72 & 33 & 76 \\
\hline
\end{tabular}

$N . R$. no reaction

a Two equiv of vinyl acetate, and a same amount of lipase, as diol $\mathbf{5}$, were used

b Determined by ${ }^{1} \mathrm{H}$ NMR

c Determined by chiral HPLC analysis

\section{5-(tert-Butoxy)-2-((tert-butoxycarbonyl)}

amino)-2-(hydroxymethyl)-5-oxopentyl hexanoate (7) (lipase TL-catalyzed enzymatic reaction, entry 3 in Table 2)

To a stirred solution of diol $5(9.6 \mathrm{mg}, 0.030 \mathrm{mmol})$ in $\mathrm{CH}_{2} \mathrm{Cl}_{2}(0.600 \mathrm{~mL})$ at $\mathrm{rt}$ were added lipase TL $(9.8 \mathrm{mg})$ and vinyl hexanoate $(0.0096 \mathrm{~mL}, 0.063 \mathrm{mmol})$. After 2 days, the reaction mixture was warmed to $35{ }^{\circ} \mathrm{C}$. After $6 \mathrm{~h}$, insoluble materials were removed by filtration through a pad of Celite, and the filtrate was concentrated in vacuo. Chiral HPLC analysis [Chiralcel IC column, $20 \%$ ethanol in hexane, $1.0 \mathrm{~mL} / \mathrm{min}, \lambda=210 \mathrm{~nm}$, $\mathrm{tR}=5.8$, 6.9 (major)] of the residue showed that the reaction proceeded in 34\% yield with 84.9:15.1 enantioselectivity. The crude material was purified by silica gel column chromatography $(500 \mathrm{mg}$, EtOAc/hexane $=3: 7)$ to give monohexanoate 7 (70 \% ee, $4.3 \mathrm{mg}, 0.010 \mathrm{mmol}$, $34 \%)$ as a white solid: $[\alpha]_{\mathrm{D}}^{22}-3.45\left(c 0.21, \mathrm{CHCl}_{3}\right)$; IR (film) 3367, 2931, 2360, 1722, 1509, $1367 \mathrm{~cm}^{-1}$; ${ }^{1} \mathrm{H}$ NMR $\left(400 \mathrm{MHz}, \mathrm{CDCl}_{3}\right) \delta 4.88(\mathrm{br}, 1 \mathrm{H}), 4.27(\mathrm{~d}, J=11.3 \mathrm{~Hz}$, $1 \mathrm{H}), 4.12(\mathrm{~d}, J=11.3 \mathrm{~Hz}, 1 \mathrm{H}), 3.61(\mathrm{~d}, J=12.0 \mathrm{~Hz}, 1 \mathrm{H})$, $3.54(\mathrm{~d}, J=12.2 \mathrm{~Hz}, 1 \mathrm{H}), 2.32(\mathrm{t}, J=7.6 \mathrm{~Hz}, 2 \mathrm{H}), 2.26$ $(\mathrm{t}, J=7.3 \mathrm{~Hz}, 2 \mathrm{H}), 2.06(\mathrm{~m}, 1 \mathrm{H}), 1.85(\mathrm{~m}, 1 \mathrm{H}), 1.61(\mathrm{t}$, $J=7.4 \mathrm{~Hz}, 2 \mathrm{H}), 1.42(\mathrm{~s}, 9 \mathrm{H}), 1.41(\mathrm{~s}, 9 \mathrm{H}), 1.33-1.24(\mathrm{~m}$, $4 \mathrm{H}), 0.88(\mathrm{t}, J=6.9 \mathrm{~Hz}, 3 \mathrm{H}) ;{ }^{13} \mathrm{C} \mathrm{NMR}\left(100 \mathrm{MHz}, \mathrm{CDCl}_{3}\right)$ $\delta$ 173.9, 173.1, 155.7, 81.0, 77.2, 65.0, 64.8, 58.2, 34.2, 31.3, 29.4, $28.3(\times 3), 28.1(\times 3), 27.6,24.6,22.3,13.9$. 
Table 2 Screening of solvents in acetylation of diol 5 mediated by lipase $\mathrm{TL}^{\mathrm{a}}$
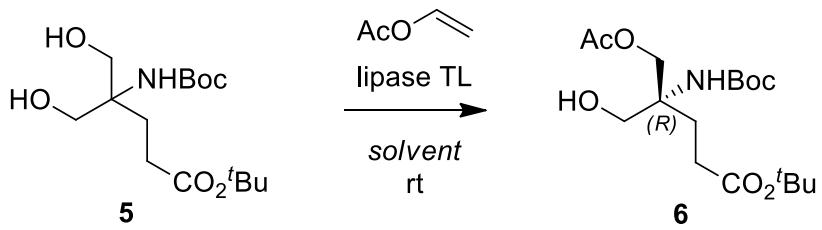

\begin{tabular}{lllll}
\hline Entry & Solvent $(\log \boldsymbol{P})$ & Time $(\mathbf{h})$ & Isolated yield (\%) & Ee of $\mathbf{6}(\%)^{\mathbf{f}}$ \\
\hline $1^{\mathrm{b}}$ & $\mathrm{CH}_{2} \mathrm{Cl}_{2}\left(1.25^{\mathrm{c}}\right)$ & 72 & 30 & 76 \\
2 & $\mathrm{Hexane}\left(3.5^{\mathrm{c}}\right) / \mathrm{THF}$ & 14 & 32 & 63 \\
& $\left(0.49^{\mathrm{d}}\right)(1: 1)$ & & & 62 \\
3 & $\mathrm{iPr}_{2} \mathrm{O}\left(1.9^{\mathrm{d}}\right)$ & 48 & 50 & 38 \\
4 & Benzene $\left(2.0^{\mathrm{c}}\right)$ & 15 & 60 & 64 \\
5 & Vinyl acetate & 2.5 & 63 & \\
\hline
\end{tabular}

\footnotetext{
a Two equiv of vinyl acetate (except for entry 5), and a same amount of lipase, as diol 5, were used

b Same reaction shown in Table 1, entry 8

c Taken from the recent paper by Salihu and Alam (2015)

d Taken from Lee's paper (Lee et al. 2004)

e A calculated value taken from SciFinder Scholar (April 17, 2015)

${ }^{f}$ Determined by chiral HPLC analysis
}

\section{(S)-2-(Acetoxymethyl)-5-(tert-butoxy)-2-((tert-butoxycar} bonyl)amino)-5-oxopentanoic acid (8)

To a vigorously stirred solution of alcohol $6(6.56 \mathrm{mg}$, $0.0157 \mathrm{mmol})$ in acetone $(0.200 \mathrm{~mL})$ at rt was added a suspension of sodium metaperiodate $(42.7 \mathrm{mg}$, $0.199 \mathrm{mmol})$ and $\mathrm{RuCl}_{3} \cdot \mathrm{nH}_{2} \mathrm{O}(1.30 \mathrm{mg}, 0.00628 \mathrm{mmol})$ in water $(0.200 \mathrm{~mL})$. After $2 \mathrm{~h}$, acetone $(2 \mathrm{~mL})$ was added and organic layer was separated. Insoluble $\mathrm{Ru}$ species were removed by filtration through a pad of Celite. The filtrate was concentrated in vacuo to give crude carboxylic acid $8(7.61 \mathrm{mg})$ as a clear oil: ${ }^{1} \mathrm{H}$ NMR $(400 \mathrm{MHz}$, $\left.\mathrm{CDCl}_{3}\right) \delta 4.70(\mathrm{~d}, J=12.1 \mathrm{~Hz}, 2 \mathrm{H}), 4.42(\mathrm{br}, 1 \mathrm{H}), 2.43-$ $2.06(\mathrm{~m}, 4 \mathrm{H}), 2.04$ (s, 3H), 1.42 (br s, 18H).

\section{(S)-2-Amino-2-(hydroxymethyl)pentanedioic acid hydrochloride ((S)-2-(hydroxymethyl)glutamic acid hydrochloride, (S)-HMG.HCl, 9)}

A suspension of crude $N$-Boc-amino ester 8 (7.61 mg) thus obtained above in hydrochloric acid $(6 \mathrm{M}, 2.00 \mathrm{~mL})$ was stirred at reflux for $25 \mathrm{~h}$. The reaction mixture was then concentrated in vacuo. The residue was purified by column chromatography on reversed-phase silica gel (500 mg, water) to give (S)-2-amino-2-(hydroxymethyl) pentanedioic acid hydrochloride ((S)-HMG.HCl, 9, $3.02 \mathrm{mg}, 78 \%$ for two steps from 6) as a white solid: $[\alpha]_{\mathrm{D}}^{24}+7.1\left(c 0.15, \mathrm{H}_{2} \mathrm{O}\right) ;{ }^{1} \mathrm{H}$ NMR $\left(400 \mathrm{MHz}, \mathrm{D}_{2} \mathrm{O}\right) \delta 3.81$ $(\mathrm{d}, J=12.0 \mathrm{~Hz}, 1 \mathrm{H}), 3.58(\mathrm{~d}, J=12.0 \mathrm{~Hz}, 1 \mathrm{H}), 2.42-2.23$ (m, 2H), $2.00-1.83(\mathrm{~m}, 2 \mathrm{H}) ;{ }^{13} \mathrm{C}$ NMR (100 MHz, $\left.\mathrm{D}_{2} \mathrm{O}\right)$ $\delta 176.8,173.2,65.2,63.8,28.6,27.1$. The spectroscopic data were in good accord with those reported previously (Aydillo et al. 2011).

\section{Results and discussion}

In the present study, we decided to construct the chiral center of HMG using lipase-catalyzed asymmetric reaction. The prochiral 1,3-diol, prepared from Tris $\cdot \mathrm{HCl}$, was designed as the substrate, and several lipases were planned to be screened. Further functional group transformation was expected to give enantiomerically pure HMG.

As shown in Scheme 1, tris(hydroxymethyl)aminomethane hydrochloride (Tris. $\mathrm{HCl}, \mathbf{1}$ ) was converted to $N$-Boc-protected benzylidene acetal 2a in $52 \%$ yield over two steps including acetalization $\left(\mathrm{PhCH}(\mathrm{OMe})_{2}\right.$, TsOH, $\mathrm{DMF})$ and carbamate formation $\left(\mathrm{Boc}_{2} \mathrm{O}, \mathrm{K}_{2} \mathrm{CO}_{3}\right)$. Acetal 2a was obtained as a single isomer, wherein the amino and phenyl groups are supposed to be in cis relationships from molecular modeling using CONFLEX (Fig. 2). Here, conformational searches were carried out with the MMFF94S force field to generate the lowest energy conformation for each isomer (Fig. 2a, b), and the steric energy indicated that $\mathbf{2 a}$ is more stable by $0.28031 \mathrm{kcal} /$ mol. Since benzylidene acetal formation was apparently a thermodynamically controlled process, more stable diastereomer 2a was concluded to be likely. Unfortunately, no experimental or spectroscopic support is available so far; 2a was not obtained as a crystal suitable for X-ray analysis, and no clear NOESY cross peak was observed for stereochemical assignment. Interestingly, acetal $\mathbf{2 a}$, as well as the next aldehyde 3 (see below), has been previously synthesized (Ko et al. 2011; Schmidt and Riedl 1993) by a different route without determination of the stereochemistry, and the reported spectroscopic data are identical to those for $\mathbf{2 a}$ (and $\mathbf{3}$ ) collected in the present study.

Alcohol 2a was next converted to aldehyde 3 by LeyGriffith oxidation (TPAP, NMO, MS4A) (Griffith et al. 1987; Ley et al. 1994) in $60 \%$ yield. Wittig reaction of aldehyde 3 with tert-butyl (triphenylphosphoranylidene) acetate in $\mathrm{CH}_{2} \mathrm{Cl}_{2}$ gave $\alpha, \beta$-unsaturated ester $\mathbf{4}$ in $92 \%$ yield with exclusive $(E)$-selectivity. The molecular framework of HMG was thus constructed in these four-step reactions.

The next step is deprotection of benzylidene acetal and reduction of olefin. These two transformations were simultaneously performed under conditions for hydrogenation $\left(\mathrm{H}_{2}, 10 \% \mathrm{Pd} / \mathrm{C}, \mathrm{MeOH}\right)$ to furnish prochiral 1,3-diol 5 in $68 \%$ yield, ready for lipase-catalyzed desymmetrization.

Enantioselective desymmetrization of 1,3-diol 5 was explored using eight lipases as shown in Table 1. The lipases are stable in organic solvents and readily available, 


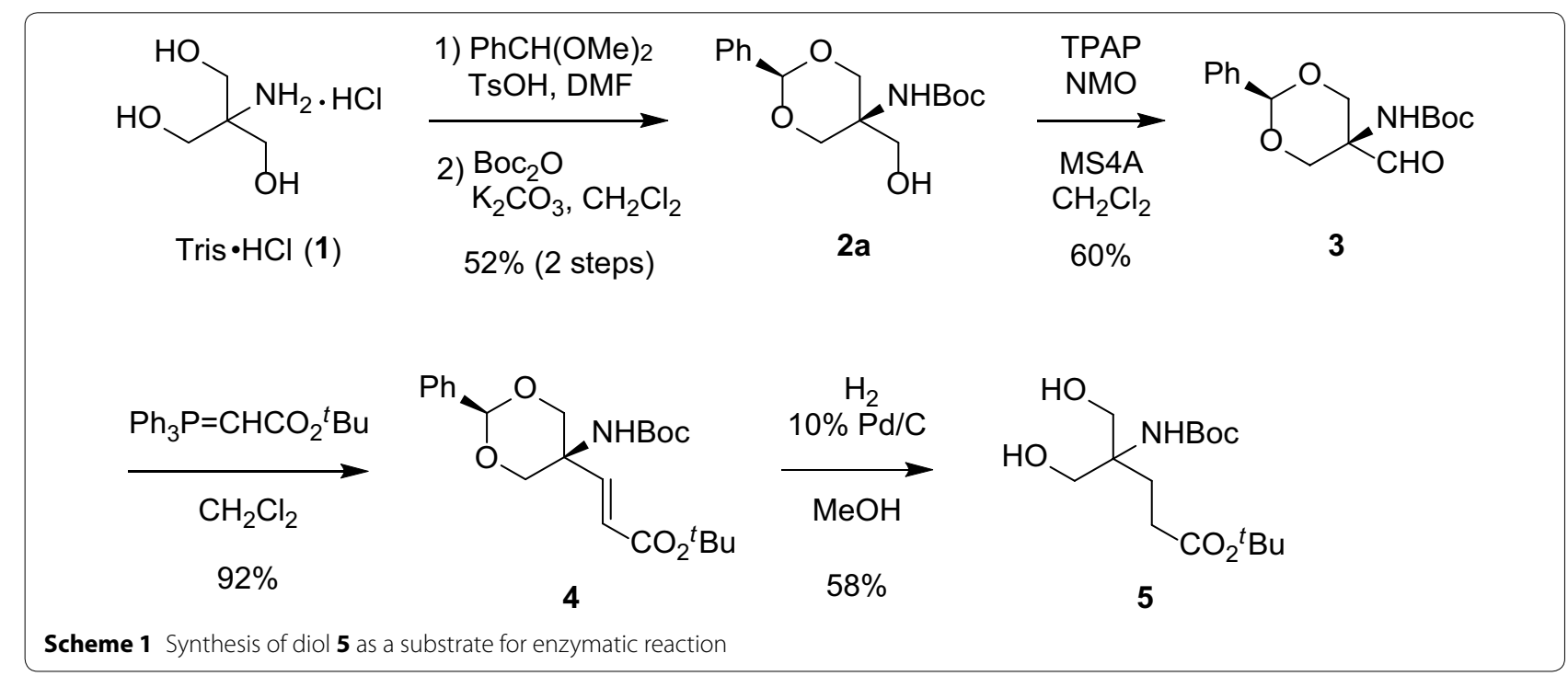

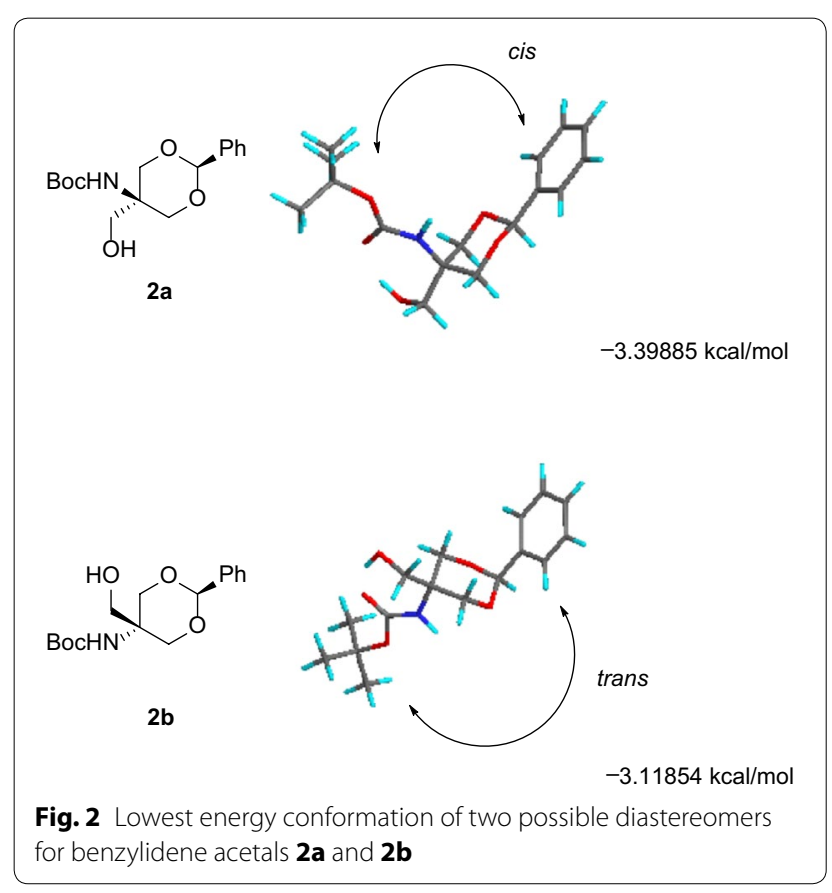

and thus were expected to allow the reaction to be performed in a large scale. All reactions were carried out using 5 (3.5-14 mg), lipase (same amount as 5), and vinyl acetate (two equiv) at $\mathrm{rt}$ in solvents indicated. The reactions were conducted until the maximum conversion was achieved as judged from TLC analysis. It was found that lipases AK (Alexandre and Huet 1998), PS-IM (Hamada et al. 2010), XP-488 (Fujima et al. 2003), and OF (Chênevert et al. 2004) do not catalyze the reaction and 1,3-diol 5 was recovered intact (entries 1-4). When lipase QLM (Naemura et al. 1996) was used for 3 days,
${ }^{1} \mathrm{H}$ NMR spectrum indicated the reaction proceeded at $59 \%$ conversion $(\mathbf{5} / \mathbf{6}=41: 59$, entry 5$)$. No other product such as diacetate was observed, and enantiomeric purity of monoacetate $\mathbf{6}$ was $47 \%$ ee as determined by chiral HPLC analysis. The stereochemistry of $\mathbf{6}$ was not determined here, but was clarified later to be $(R)$ configuration by leading to $(S)$-HMG (see below). In the following entries $6-8$, the same enantioselectivity was observed. However, with lipases PL (Alexandre and Huet 1998) and Novozyme 435 (Chênevert et al. 2004), the enantioselectivity was decreased to be $41 \%$ ee and $9.5 \%$ ee, respectively (entries 6, 7). Fortunately, it was found that lipase TL (van Pelt et al. 2011) provides enantiomerically more pure monoacetate 6 (76\% ee) at $33 \%$ conversion (30\% isolation yield) after 3 days (entry 8). Again, no diacetate was observed here chromatographically and spectroscopically, and unreacted 1,3-diol 5 was quantitatively recovered in all entries. We further studied enzymatic acylation using lipase TL to optimize reaction conditions.

Table 2 shows the isolation yield and the ee, in acetylation of $\mathbf{5}$ mediated by lipase TL, with a variety of solvents. The reaction in $\mathrm{CH}_{2} \mathrm{Cl}_{2}$, which has been shown in Table 1, entry 8, gave monoacetate 6 in $30 \%$ isolated yield (76\% ee, entry 1 ). Mixed solvent of hexane and THF (1:1) was found to give 6 in comparable yield with decreased enantioselectivity ( $63 \%$ ee, entry 2 ). Employment of $\mathrm{iPr}_{2} \mathrm{O}$ improved the yield to $50 \%$, while the level of ee was preserved (62\% ee, entry 3 ). Benzene as a solvent further improved the yield (60\%), but the enantioselectivity was largely diminished to $38 \%$ ee (entry 4 ). In entry 5, vinyl acetate was employed as a solvent, wherein the highest yield (63\%) was observed with $64 \%$ ee. In all entries no diacetate was obtained and unreacted diol 5 
was recovered quantitatively. It is generally accepted that organic solvents with high $\log P$ values (octanol-water partition coefficient) are preferably used in lipase-catalyzed reaction, because of their poor ability to remove essential water molecules from lipase (Salihu and Alam 2015). In our case shown in Table 3 , however, no obvious correlation was observed between the isolated yield and $\log P$ of the solvent.

Lipase TL also mediated esterification with longer acyl group (Tsuji et al. 2005) at, in some cases, elevated temperature (Table 3 ). Three solvents were examined with two equiv of vinyl hexanoate. Entry 1 shows hexanoylation in $\mathrm{iPr}_{2} \mathrm{O}$. The reaction slowly proceeded at $50{ }^{\circ} \mathrm{C}$ over $19 \mathrm{~h}$ to give hexanoate 7 in $30 \%$ conversion yield. Enantioselectivity was disappointingly low $(6.4 \%$ ee) as determined from chiral HPLC analysis. However, the results were improved when benzene was employed (entry 2); benzene allows hexanoylation at rt to provide 7 in $70 \%$ yield with $65 \%$ ee. Even higher enantioselectivity (70\% ee) was observed in $\mathrm{CH}_{2} \mathrm{Cl}_{2}$ (entry 3), whereas the yield decreased to $34 \%$. As for the enantioselectivity, thus, $\mathrm{CH}_{2} \mathrm{Cl}_{2}$ was found to be practical in both acetylation and hexanoylation.

In nature, lipases catalyze hydrolysis of ester to give carboxylic acid by (A) nucleophilic attack of the active site serine to the ester carbonyl group to form acyl-enzyme intermediate, (B) which then suffers hydrolysis (Ghanem 2007; Adlercreutz 2013). Transesterification (alcoholysis of ester) by lipase is believed to proceed by the same mechanism, and interactions between the acylated enzyme active site and the alcohol, involved in the second event (e.g. B), influence the rate of the reaction. The only modest enantioselectivities and yields observed in Tables 1, 2 and 3 would be due to rather severe interactions caused by sterically demanding alcohol substrate 5 .

With monoacetate $\mathbf{6}$ in hand, we continued the synthetic study toward 2-(hydroxymethyl)glutamic acid (HMG) (Scheme 2). The enantiomeric purity of $\mathbf{6}$ was first enhanced to $100 \%$ ee by preparative chiral HPLC. The stereochemistry of $\mathbf{6}$ was expected to be clarified by comparison of the physical or chromatographic properties of our synthetic HMG with authentic specimens. Thus, $\mathrm{RuO}_{4}$-mediated oxidation (Oba et al. 2006) of alcohol 6 afforded carboxylic acid 8, which is the protected precursor for HMG. Finally, $N$-Boc-amino ester 8 was hydrolyzed in refluxing $6 \mathrm{M}$ hydrochloric acid to give $\mathrm{HMG} \cdot \mathrm{HCl}$ (9) in $78 \%$ yield (two steps). Optical rotation data $\left[(\alpha)_{\mathrm{D}}^{24}+7.1\left(c 0.15, \mathrm{H}_{2} \mathrm{O}\right)\right]$ indicated the $(S)$ configuration (Aydillo et al. 2011). (S)-2-(Hydroxymethyl) glutamic acid hydrochloride (9) was thus synthesized in $12 \%$ overall yield for eight steps starting from Tris. $\mathrm{HCl}$.

\section{Conclusions}

In this paper, we demonstrated enantioselective synthesis of (S)-HMG (9) employing lipase-catalyzed asymmetric esterification of prochiral 1,3-diol 5. Overall yield was $12 \%$ for total eight steps. As compared to the other shorter step syntheses of HMG (Zhang et al. 2001; Aydillo et al. 2011), our work is obviously not satisfactory (see Additional file 1 for summary for previous synthetic study of HMG). Nevertheless, we believe our present results are advantageous to provide the additional way to produce not only $(S)$-HMG but also the $(R)$ congener, since hydroxy groups of the intermediate $\mathbf{6}$ are

Table 3 Screening of solvents for hexanoylation of diol 5 mediated by lipase $\mathrm{TL}^{\mathrm{a}}$

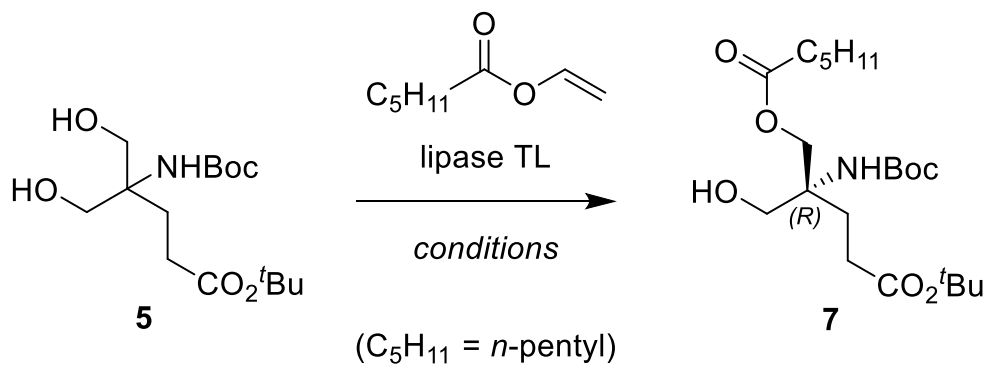

\begin{tabular}{lll}
\hline Entry & Conditions & Conversion (\%) $^{\mathbf{b}}$ \\
\hline 1 & $\mathrm{iPr}_{2} \mathrm{O}, \mathrm{rt} \rightarrow 50{ }^{\circ} \mathrm{C}, 19 \mathrm{~h}$ & 30 \\
2 & $\mathrm{Benzene}, \mathrm{rt}, 48 \mathrm{~h}$ & 70 \\
3 & $\mathrm{CH}_{2} \mathrm{Cl}, \mathrm{rt} \rightarrow 35^{\circ} \mathrm{C}, 54 \mathrm{~h}$ & 34 \\
\hline
\end{tabular}

\footnotetext{
a Two equiv of vinyl hexanoate, and a same amount of lipase, as diol $\mathbf{5}$, were used

b Determined by ${ }^{1} \mathrm{H}$ NMR

c Determined by chiral HPLC analysis
} 


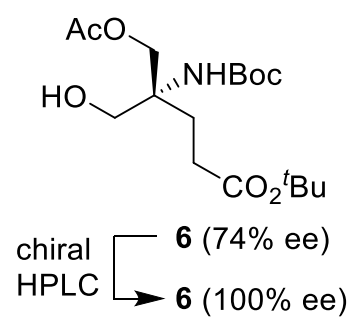

Scheme 2 Final elaboration toward (S)-HMG (9)
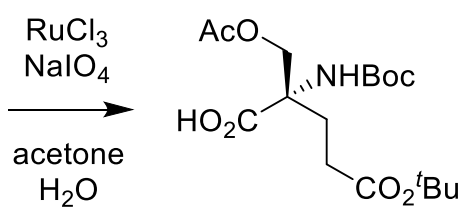

8

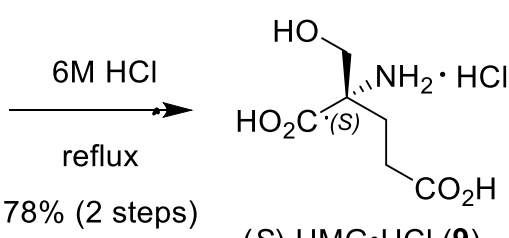

$(\mathrm{S})-\mathrm{HMG} \cdot \mathrm{HCl}(\mathbf{9})$

$$
[\alpha]_{D}^{24}+7.1\left(c 0.15, \mathrm{H}_{2} \mathrm{O}\right)
$$

Lit (Aydillo et al. 2011): $[\alpha]_{D}{ }^{25}+6.4\left(c 0.99, \mathrm{H}_{2} \mathrm{O}\right)$

orthogonally derivatized. Moreover, the present synthesis pathway is also applicable to other biologically important class of $\alpha, \alpha$-disubstituted amino acid such as dysibetaine (Sakai et al. 1999), sphingofungin E (Horn et al. 1992), and other related natural products. Works are in progress toward these compounds, and the results will be reported in due course.

\section{Additional file}

Additional file 1. NMR spectra for all new compounds, chiral HPLC profile for monoacetate $\mathbf{6}$, and a summary for previous synthetic study of HMG.

\section{Abbreviations}

CNS: central nervous system; GPCR: G-protein-coupled receptor; HMG: (hydroxymethyl)glutamic acid; HPLC: high-performance liquid chromatography; log P: octanol-water partition coefficient; mGluR: metabotropic glutamate receptor; TLC: thin-layer chromatography; Tris.HCl: tris(hydroxymethyl) aminomethane hydrochloride.

\section{Authors' contributions}

$\mathrm{MO}$ designed the research; $\mathrm{HY}$ and $\mathrm{MO}$ conducted the research and analyzed the data; $\mathrm{HY}$ and $\mathrm{MO}$ wrote the paper and approved the final manuscript. Both the authors read and approved the final manuscript.

\section{Acknowledgements}

Lipase TL was a generous gift from Meito Sangyo Co., Ltd., Japan. We thank Prof. Takeshi Sugai (Keio University, Japan) for invaluable discussions. This work was financially supported by a Grant-in-Aid for Scientific Research (26282216) from the Ministry of Education, Science, Sports, Culture and Technology, Japan.

\section{Competing interests}

The authors declare that they have no competing interests.

Received: 15 July 2015 Accepted: 3 November 2015

Published online: 24 November 2015

\section{References}

Adlercreutz P (2013) Immobilisation and application of lipases in organic media. Chem Soc Rev 42:6406-6436. doi:10.1039/C3CS35446F

Alexandre F-R, Huet F (1998) Asymmetrization of meso-1,3-diols utilising Pseudomonas fluorescens lipase. Tetrahedron Asymmetry 9:2301-2310. doi:10.1016/S0957-4166(98)00237-7
Aydillo C, Jimenez-Oses G, Avenoza A, Busto JH, Peregrina JM, Zurbano MM (2011) A domino Michael/Dieckmann process as an entry to a-(Hydroxymethyl)glutamic acid. J Org Chem 76:6990-6996. doi:10.1021/ jo201067n

Battistini L, Curti C, Zanardi F, Rassu G, Auzzas L, Casiraghi G (2004) Enantioselective total synthesis of $(1 R, 3 S, 4 R, 5 R)$-1-amino-4,5-dihydroxycyclopentane-1,3-dicarboxylic acid. A full-aldol access to carbaketose derivatives. J Org Chem 69:2611-2613. doi:10.1021/jo035846a

Chênevert R, Duguay D, Touraille F, Caron D (2004) Enzymatic desymmetrization of 5-bis(hydroxymethyl)tetrahydro-2-furanone: a template for protein kinase C ligands. Tetrahedron Asymmetry 15:863-866. doi:10.1016/j. tetasy.2004.01.030

Chiba M, Fujimoto C, Sakai R, Oikawa M (2015) Structure-activity relationships of IKM-159: diverted synthesis and biological evaluation of a series of C5-oxy analogs. Bioorg Med Chem Lett 25:1869-1871. doi:10.1016/j. bmcl.2015.03.037

Choudhury PK, Le Nguyen BK, Langlois N (2002) Stereoselective synthesis of (2S)-2-hydroxymethylglutamic acid, a potent agonist of metabotropic glutamate receptor mGluR3. Tetrahedron Lett 43:463-464. doi:10.1016/ S0040-4039(01)02196-7

Fujima Y, Hirayama Y, Ikunaka M, Nishimoto Y (2003) A scalable chemoenzymatic preparation of (R)-tetrahydrofuran-2-carboxylic acid. Tetrahedron Asymmetry 14:1385-1391. doi:10.1016/S0957-4166(03)00249-0

Ghanem A (2007) Trends in lipase-catalyzed asymmetric access to enantiomerically pure/enriched compounds. Tetrahedron 63:1721-1754. doi:10.1016/.tet.2006.09.110

Griffith WP, Ley SV, Whitcombe GP, White AD (1987) Preparation and use of tetra-n-butylammonium per-ruthenate (TBAP reagent) and tetra-n-propylammonium per-ruthenate (TPAP reagent) as new catalytic oxidants for alcohols. J Chem Soc, Chem Commun. doi:10.1039/C39870001625

Hamada M et al (2010) Chemoenzymatic synthesis of (2S,3S,4S)-form, the physiologically active stereoisomer of dehydroxymethylepoxyquinomicin (DHMEQ), a potent inhibitor on NF-kB. Tetrahedron 66:7083-7087. doi:10.1016/j.tet.2010.07.013

Hayes CJ, Bradley DM, Thomson NM (2006) An efficient enantioselective synthesis of (2R)-hydroxymethyl glutamic acid and an approach to the (2R)hydroxymethyl-substituted sphingofungins. J Org Chem 71:2661-2665. doi:10.1021/jo052408q

Horn WS et al (1992) Sphingofungins E and F: novel serinepalmitoyl transferase inhibitors from Paecilomyces variotii. J Antibiot (Tokyo) 45:1692-1696

Juknaite L et al (2013) Studies on an (S)-2-amino-3-(3-hydroxy-5-methyl-4-isoxazolyl)propionic acid (AMPA) receptor antagonist IKM-159: asymmetric synthesis, neuroactivity, and structural characterization. J Med Chem 56:2283-2293. doi:10.1021/jm301590z

Kawasaki M, Namba K, Tsujishima H, Shinada T, Ohfune Y (2003) Efficient synthesis of optically active a-substituted glutamate analogs possessing a-hydroxymethyl and a-alkoxymethyl groups. Tetrahedron Lett 44:1235-1238. doi:10.1016/50040-4039(02)02810-1

Ko RYY, Chu JCK, Chiu P (2011) Synthesis of fluorinated analogues of the immunosuppressive drug FTY720. Tetrahedron 67:2542-2547. doi:10.1016/j.tet.2011.02.028

Lee YS, Hong JH, Jeon NY, Won K, Kim BT (2004) Highly enantioselective acylation of rac-alkyl lactates using Candida antarctica lipase B. Org Process Res Dev 8:948-951. doi:10.1021/op0498722 
Ley SV, Norman J, Griffith WP, Marsden SP (1994) Tetrapropylammonium Perruthenate, $\mathrm{Pr}_{4} \mathrm{~N}^{+} \mathrm{RuO}_{4}{ }^{-}$, TPAP: a Catalytic Oxidant for Organic Synthesis. Synthesis 1994:639-666. doi:10.1055/s-1994-25538

Martinkova M, Gonda J, Raschmanova J, Uhrikova A (2008) Stereoselective synthesis of both enantiomers of a-(hydroxymethyl)glutamic acid. Tetrahedron Asymmetry 19:1879-1885. doi:10.1016/j.tetasy.2008.08.003

Miyaoka H, Yamanishi M, Hoshino A, Kinbara A (2006) (R)-4-Hydroxymethyl2-phenyl-4,5-dihydrooxazol-4-ylmethyl acetate: chiral building block for the synthesis of optically active $a$-substituted a-amino acid derivatives. Tetrahedron 62:4103-4109. doi:10.1016/j.tet.2006.02.022

Naemura K, Murata M, Tanaka R, Yano M, Hirose K, Tobe Y (1996) Enantioselective acylation of primary and secondary alcohols catalyzed by lipase QL from Alcaligenes sp.: a predictive active site model for lipase QL to identify which enantiomer of an alcohol reacts faster in this acylation. Tetrahedron Asymmetry 7:3285-3294. doi:10.1016/0957-4166(96)00429-6

Niswender CM, Conn PJ (2010) Metabotropic glutamate receptors: physiology, pharmacology, and disease. Annu Rev Pharmacol Toxicol 50:295-322. doi:10.1146/annurev.pharmtox.011008.145533

Oba M et al (2006) Preparation of L-serine and L-cystine stereospecifically labeled with deuterium at the $\beta$-position. Tetrahedron Asymmetry 17:1890-1894. doi:10.1016/j.tetasy.2006.06.039

Oikawa M, Sugeno Y, Ishikawa Y, Tukada H (2013) A synthesis of (-)-cis-2-Aminomethylcyclopropanecarboxylic Acid [(-)-CAMP]. Synlett 24:886-888. doi:10.1055/s-0032-1317802

Rondard P, Pin J-P (2015) Dynamics and modulation of metabotropic glutamate receptors. Curr Opin Pharmacol 20:95-101. doi:10.1016/j. coph.2014.12.001

Sakai R, Oiwa C, Takaishi K, Kamiya H, Tagawa M (1999) Dysibetaine: a new a,a-disubstituted a-amino acid derivative from the marine sponge Dysidea herbacea. Tetrahedron Lett 40:6941-6944. doi:10.1016/ S0040-4039(99)01356-8

Sakai M, Tanaka K, Takamizawa S, Oikawa M (2014) Enantiodivergent syntheses of (-)- and (+)-dysibetaine CPa and N-desmethyl analog. Tetrahedron 70:4587-4594. doi:10.1016/j.tet.2014.05.053
Salihu A, Alam MZ (2015) Solvent tolerant lipases: a review. Process Biochem 50:86-96. doi:10.1016/j.procbio.2014.10.019

Schmidt U, Riedl B (1993) The total synthesis of antrimycin Dv; Ill: construction of the protected hexapeptide and deprotection. Synthesis 1993:815-818. doi:10.1055/s-1993-25948

Sugeno Y, Ishikawa Y, Oikawa M (2014) Asymmetric Organocatalytic Cyclopropanation on Chiral Menthyl Acrylate for the Synthesis of (-)-trans-2-Aminomethylcyclopropanecarboxylic Acid [(-)-TAMP]. Synlett 25:987-990. doi:10.1055/s-0033-1340953

Tanaka K, Sakai M, Takamizawa S, Oikawa M (2015) Enantioselective synthesis of (+)- $\mathrm{N}$-(desmethyl)dysibetaine CPb. Chem Lett 44:253-255. doi:10.1246/cl.141049

Tang G, Tian H, Ma D (2004) Asymmetric Strecker reaction of $\gamma$-keto acids. Facile entry to a-substituted and $a, \gamma$-disubstituted glutamic acids. Tetrahedron 60:10547-10552. doi:10.1016/j.tet.2004.07.100

Tsuji T, lio Y, Takemoto T, Nishi T (2005) Enzymatic desymmetrization of 2-amino-2-methyl-1,3-propanediol: asymmetric synthesis of (S)-N-BocN,O-isopropylidene-a-methylserinal and (4R)-methyl-4-[2-(thiophen2-yl)ethyl]oxazolidin-2-one. Tetrahedron Asymmetry 16:3139-3142. doi:10.1016/j.tetasy.2005.07.037

van Pelt S et al (2011) Pseudomonas stutzeri lipase: a useful biocatalyst for aminolysis reactions. Green Chem 13:1791-1798. doi:10.1039/C1GC15160F

Yiotakis A, Magriotis PA, Vassiliou S (2007) A simple synthesis of the metabotropic receptor ligand (2S)-a-(hydroxymethyl)-glutamic acid and its Fmoc protected derivatives. Tetrahedron Asymmetry 18:873-877. doi:10.1016/j. tetasy.2007.03.028

Zhang J, Flippen-Anderson JL, Kozikowski AP (2001) A tandem Michael addition ring-closure route to the metabotropic receptor ligand a-(hydroxymethyl)glutamic acid and its $\gamma$-alkylated derivatives. J Org Chem 66:7555-7559. doi:10.1021/jo010626n

\section{Submit your manuscript to a SpringerOpen ${ }^{\circ}$ journal and benefit from:}

- Convenient online submission

- Rigorous peer review

- Immediate publication on acceptance

- Open access: articles freely available online

- High visibility within the field

- Retaining the copyright to your article

Submit your next manuscript at $>$ springeropen.com 